\title{
Strategy in Theory; Strategy in Practice
}

\author{
Hew Strachan ${ }^{\mathrm{a} *}$ \\ ${ }^{a}$ School of International Relations, University of St Andrews, St Andrews, UK \\ Corresponding author: Hew Strachan, School of International Relations, University of St \\ Andrews, St Andrews, Fife, KY 16 9AX, Scotland, UK, hew.strachan@all-souls.ox.ac.uk
}

Hew Strachan, FBA, FRSE, Hon. D. Univ (Paisley) has been Professor of International Relations at the University of St Andrews since 2015. He is a Life Fellow of Corpus Christi College, Cambridge, where he taught from 1975 to 1992, before becoming Professor of Modern History at Glasgow University from 1992 to 2001. He was Chichele Professor of the History of War at the University of Oxford and a Fellow of All Souls College 2002-15 (where he is now an Emeritus Fellow), and Director of the Oxford Programme on the Changing Character of War 2003-2012. He serves on the Strategic Advisory Panel of the Chief of the Defence Staff and on the UK Defence Academy Advisory Board, as well as being a trustee of the Imperial War Museum (until February 1918), a Commonwealth War Graves

Commissioner, and member of the national committees for the centenary of the First World War of the United Kingdom, Scotland and France. In 2010 he chaired a task force on the implementation of the Armed Forces Covenant for the Prime Minister. In 2011 he was the inaugural Humanitas Visiting Professor in War Studies at the University of Cambridge and became a specialist adviser to the Joint Parliamentary Committee on the National Security Strategy. He is a Brigadier in the Queen's Bodyguard for Scotland (Royal Company of Archers). In December 2012, Foreign Policy magazine included him in its list of top global thinkers for the year. He was knighted in the 2013 New Year's Honours, and was appointed Lord Lieutenant of Tweeddale in 2014. In 2016 he was awarded the Pritzker Prize for Lifetime Achievement for Military Writing. His recent publications include The Politics of the British Army (1997); The First World War: To Arms (2001); The First World War: a New Illustrated History (2003); and The Direction of War (2013). 


\section{Strategy in Theory; Strategy in Practice}

The practice of strategy is different from strategic theory. The latter was largely developed by professional soldiers from the experiences of the Napoleonic Wars, and compared the present with the past to establish general truths about war. It used history as its dominant discipline until 1945. The advent of nuclear weapons made history seem less relevant, and prompted the inclusion of other disciplines; deterrence theory also made strategic theory more abstract and distant from the practice of war. Since 9/11, the experience of war has forced strategy to become less theoretical and to do better in reconciling theory with practice.

Keywords: strategy; military strategy; grand strategy; maritime strategy; operations

In his book, Modern Sstrategy, published in 1999, Colin Gray declared with his customary forcefulness (and the italics are his): 'there is an essential unity to all strategic experience in all periods of history because nothing vital to the nature and function of war and strategy changes'. ${ }^{1}$ Gray is not alone among scholars working on the place of war in international relations who see history as a continuum. Edward Luttwak, Beatrice Heuser and Lawrence Freedman have taken similar lines, albeit with less directness. Nor are they wrong to do so: it is better that history contributes to an understanding of war and strategy than it does not. However, history is not just a repository from which we cherry-pick enduring truths. If it were, there would be little value in obeying Michael Howard's injunction that we study military history in width, depth and context. ${ }^{2}$ The more we do that, the more we see nuance, difference, and even discontinuity.

' Colin S. Gray, Modern Sstrategy (Oxford: Oxford University Press 1999), 1. Colin Gray has responded to the criticism which follows in The Strategy Bridge: Theory for Practice (Oxford: Oxford University Press 2010), 10. Similar assumptions underpin John Lewis Gaddis, On grand strategy (London: Allen Lane 2018).

${ }^{2}$ Michael Howard, The Causes of Wars and Other Essays (London: Temple Smith 1983), 195-197. 
Colin Gray is a student of politics with a strong interest in history; this essay is written by a historian with a strong interest in policy. The value that Gray sees in history is a sense of continuity. Many historians, particularly those who look to the longue durée, set out with a similar purpose. There is no more telling or acerbic critic of those determined to describe a current development as unprecedented than the historian - who rightly says that there is nothing new about the rise of non-state actors in war, or about the incidence of civil war, or about the inter-weaving of crime and war. But what also attracts historians is the study of change: the causes of the French or Russian revolutions, the outbreak of the First World War, the end of the Cold War, the impact of the 9/11 attacks. Those who lived through those events were conscious of epoch-making change, and - however much we may soften their disruptive effects as we seek context and distance - we distort the past if we strive too zealously to minimise the impact of contingency or the effect of shock. Explaining change is both more difficult and more contentious (as testified by the enduring capacity of explanations for the major caesuras in world history to generate controversy) than accounting for continuity.

What we understand by strategy in particular has changed considerably over time. The word did not become current until the late eighteenth century and was not in regular use until after the final defeat of Napoleon in 1815. Napoleon himself did not employ it, at least during his active career: his critics might say it would have been to his advantage if he had. ${ }^{3}$ However, that point itself illustrates the effect of change. Carl von Clausewitz, who was responding to the impact of Napoleon on war and who used his magnum opus Vom Kriege to develop the understanding which he derived from his own experience of Napoleonic warfare,

${ }_{3}^{3}$ Napoléon, De la guerre, presenté et annoté par Bruno Colson (Paris: Perrin 2011), 148. 
regularly defined strategy as 'the use of the engagement for the purpose of the war'. ${ }^{4}$ For him - as for Napoleon - battle lay at the centre of strategy, just as it did of war. But for modern tastes that approach is both too operational and insufficiently political. It defines strategy in ways that are narrowly military and therefore introspective. Decisive battle, as it was understood in the age of Frederick the Great or Napoleon, all but disappeared from warfare over the course of the twentieth century. The so-called battles of the First World War, of which Verdun and the Somme might stand as exemplars, lasted months and were not decisive. They had to be rationalised in new ways, through the vocabulary of attrition, a strategic idea which those wedded to the old forms of war vehemently rejected as nihilistic. ${ }^{5}$

That debate ought to have raised more profound and fundamental questions about the strategic theories which took battle's centrality for granted than it did. After the First World War, Basil Liddell Hart developed a model of strategy which - in focusing on the 'indirect approach' - de-emphasised battle. ${ }^{6} \mathrm{He}$ went on, as he put it, to 're-frame' strategy by aligning it more closely with the use of military means to fulfil the ends of government. ${ }^{7}$ In other words strategy now looked outwards to its relationship with policy. Battle was not an end in itself, as it was for Napoleon, but a means to an end - and very often, and even increasingly, an optional one. This more modern understanding of strategy is that with which Colin Gray works. It is also fuels Napoleon's critics, who denounce him for failing to see that the purpose of war was not to create the conditions for the next battle but the capacity to convert

4 Carl von Clausewitz, On War, translated and edited by Michael Howard and Peter Paret (Princeton: Princeton University Press 1976), 128, 177.

s Friedrich von Bernhardi, Vom Kriege der Zukunft. Nach der Erfahrungen des Weltkrieges (Berlin: E.S. Mittler \& Sohn 1920), 136-137.

- Basil Liddell Hart, The Decisive Wars of History: A Study in Strategy (London: G. Bell \& Sons Ltd 1929), which became The Strategy of the Indirect Approach (London: Faber \& Faber 1942).

' Basil Liddell Hart, 'Strategy re-framed', in When Britain Goes to War: Adaptability and Mobility (London, Faber \& Faber 1932). 
war into a lasting peace. It behoves all those who read Clausewitz today in order to acquire a better comprehension of war to realise that, when he used the word 'strategy', he meant something very different from those who write about strategy today.

This distinction - strategy as the use of the battle for the purposes of war and strategy as the use of war for the purposes of policy - has become muddled, for perfectly understandable reasons. To be sure, titles like 'military' strategy on the one hand, and 'grand' or 'national' strategy on the other, convey the difference between the operational and political levels. British joint operational doctrine in 2004 stated that 'as the military component of strategy, military strategy is the process by which military objectives and force levels, which will assist in the achievement of political objectives, are decided'. It went on to stress that 'any document setting out a military strategy must contain an explanation of how the military strategy is to be integrated with other non-military elements of the national strategy' ${ }^{8}$ Although these distinctions reflect NATO doctrines, we are far from rigorous in their application, and understandably so. Steven Jermy, writing on strategy in 2011, included a heading for 'military strategy' in his index, but then said 'see politico-military strategy'. ${ }^{9} \mathrm{He}$ is not alone in his desire to reject a division between 'military' strategy and strategy more generally. John Stone, in a book published in the same year as Jermy's and explicitly titled Military strategy, addressed not the process by which military objectives and force levels are set, but 'the instrumental link between military means and political ends'. For Stone the value of the epithet 'military' lay not in the distinction between the self-contained world of the soldier and the political level, which he saw as necessarily linked rather than bifurcated, but in the distinction between 'military strategy' and grand strategy, 'an activity that is concerned

${ }^{8}$ Joint Doctrine Publication 01: Joint Operations (Joint Doctrine and Concepts Centre, March 2004), para 208, 2-3-2-4.

9 Steven Jermy, Strategy for Action: Using Force Wisely in the $21^{\text {st }}$ Century (London:

Knightstone Publishing 2011), 327. 
with the application of the totality of national resources in the pursuit of political goals' ${ }^{10}$ The multiplicity of meanings linked to 'military strategy' does not stop there. For example, some employ it to convey the distinction between strategy as an instrument of statecraft and its use in non-military contexts, particularly business. ${ }^{11}$

Paradoxically, the concepts which underpin 'grand strategy' may possess greater antiquity than do those around the operational meanings of strategy developed over the course of the 'long' nineteenth century. Pre-modern rulers may not have used the phrase 'grand strategy', but they certainly had to address the relationship between war and peace, and to understand the utility of military force within it. This is the justification for the inclusion of Thucydides's history of the Peloponnesian war on war college syllabuses, and for Edward Luttwak's determination to describe what he calls the 'grand strategies' of the Roman and Byzantine empires. ${ }^{12}$ Historians of the Renaissance and early modern Europe have become increasingly comfortable with 'grand strategy' as a description of the policies pursued by their subjects: consider for example the work of Geoffrey Parker in looking at imperial Spain and the case of Philip II. ${ }^{13}$ In that sense it was the very invention of more modern 'operational' understandings of strategy by Clausewitz and his contemporary, Antoine-Henri Jomini, which first precipitated the very confusion we now confront. The century-long effort to digest the impact of Napoleon coincided with the rise - not least

\footnotetext{
${ }^{10}$ John Stone, Military Strategy: The Politics and Technique of War (London: Continuum, 2011), 4.

${ }^{11}$ Hervé Coutau-Bégarie, Traité de stratégie (6 $6^{\text {th }}$ edition, Paris: Economica 2008), 88-90.

${ }^{12}$ Edward N. Luttwak, The Grand Strategy of the Roman Empire from the First Century A.D. to the Third (1976) (London: Weidenfeld \& Nicolson 1999); Edward N. Luttwak, The Grand Strategy of the Byzantine Empire (Cambridge MA: The Belknap Press of Harvard University Press 2009).

${ }^{13}$ Geoffrey Parker, The Grand Strategy of Philip II (New Haven, CT: Yale University Press 1998). This paragraph reflects a conference on 'Strategy and its making in early modern Europe', held at the University of St Andrews in honour of Geoffrey Parker, 29-30 April 2016.
} 
intellectually - of the military profession, and the notion of strategy as embedded within war was part and parcel of the self-validation of career officers.

This changed after 1945. The Charter of the United Nations had more to say about the role of international law in causing or forestalling war, ius ad bellum, than it did about the conduct of war, ius in bello. During the Cold War the threat of the use of war in order to preserve the global order - deterrence - became the principal function of many armed forces. Strategy in other words was as much, if not more, about preventing war as waging it. Strategy did indeed shape foreign policy, and foreign policy in turn was shaped disproportionately by strategic theory, as expressed in ideas like deterrence. Indeed, so theoretical was nuclear strategy, and so divorced from actual war, that from the late 1950s onwards it was largely developed by academics, most of them not historians.

In some respects these changes can be seen as 'change back', a reversion to something that had existed before, as much as change de novo. Strategy re-acquired the power political connotations of which the military profession had robbed it in the years between Napoleon and Hitler. It ceased to be the monopoly of generals and military professionals, who became marginalised in its development. Since the Cold War's end we have become confused about strategy not least because the actual experience of war has required us to re-integrate the two approaches in ways that had not been necessary when war was more a threat than an actuality. As a result we are uncertain what strategy means and unclear who makes it. Is it the responsibility of its nineteenth-century protagonists, the armed forces, or of governments? Is war too important to be left to the generals, as France's prime minister in 1917-18, Georges Clemenceau, opined? Or are they the only ones who - because of their life-long professional engagement - truly understand it, as Brigadier-General Jack D. Ripper insists in Stanley Kubrick's 1964 film, Dr Strangelove, or how I learned to stop worrying and love the bomb? Ripper says that Clemenceau may have been right fifty years 
ago, but 'now war is too important to be left to the politicians. They have neither the time, the training, nor the inclination for strategic thought.' Kubrick portrayed Ripper as insane: another fifty years on and George W. Bush and Tony Blair responded to the $9 / 11$ attacks by invading Iraq, which had had no part in them, leading satirists to see statesmen, not soldiers, as warmongers.

Or is strategy the task of a joint body like a national security council? The composition of such bodies varies from country to country according to national and constitutional norms, but it has the potential to combine 'military' strategy with wider approaches to strategy, because chiefs of staff either attend meetings or are members in their own right. It can also create 'grand' strategy, because in some cases it integrates in a single body all ministers whose portfolios affect national security. The president or the prime minister is frequently in the chair. But if a national security council is the best institutional solution for the formation of strategy, and an increasing number of governments seem to think it is, why don't all states have one? Perhaps those which don't have either a national security strategy or a national security council are behaving with greater realism - precisely because they do not in fact intend to use war as an act of national policy, and this not just because they don’t want to but also because they lack the capability to do so. After all, western democracies, including the United States, have proved remarkably reluctant to go to war without allies. Given this overwhelming preference for coalition warfare, it seems absurd to continue to develop strategy in narrowly national terms.

So the first source of our current ills is that we have had to put the conduct of war, as opposed to the avoidance of war, back into our thinking. The second is the confusion as to whether western democratic states are actually at war. Since $9 / 11$ their national leaders have found it increasingly hard not to respond to terrorist threats by suggesting that they are: both David Cameron and François Hollande were cases in point, as of course was George W. 
Bush. National leaders have used the rhetoric of national mobilisation, so evoking the memory of the Second World War or - for France - the wars of the Revolution. Their peoples seem increasingly not to agree. They see no direct evidence of the fact: they are not conscripted, their taxes are not increased to pay for larger armed forces, and their daily lives continue to be conducted according to the routines of peacetime. True, their (by and large professional) armed forces are deployed in war zones and suffer casualties. And yet the west persists (and this is the third source of its confusion) in calling the conflicts in which its states have been engaged 'wars of choice'. Most citizens of western democracies probably accept that there are occasions when it may be necessary to resort to war, especially when they put necessity in the context of the Second World War, but they find it hard to regard war as a something they opt to do, as opposed to it being forced on them. Choice in this context suggests frivolity in the decision to embark on an enterprise with momentous and destructive implications.

Finally we have confused strategy in theory with strategy in practice. Those who thought about war in the wake of Napoleon were well aware of the importance of this distinction, none more so than Ferdinand Foch, the allied generalissimo in 1918. In 1914 Foch had served for forty years and reached corps command without having seen action: his views on war were shaped by study and reading, and were articulated before the First World War in the lectures he had delivered at the Ecole de Guerre. He was a strategic theorist par excellence. He then fought to defend his country for four years, at the Marne, around Ypres and on the Somme. By 1918 he realised that, important though study was, it was not sufficient: that, although strategy 'may be simply understood after it has been practised, it is not a simple thing to put into practice. What is required is the ability, in special circumstances, to appreciate the situation as it exists, shrouded in the midst of the 
unknown. ${ }^{14}$ Theory, and the plans which flow from it, were only preparatory and preliminary. 'Plans must be adapted to circumstances', he said after the First World War when reflecting on the causes of the German defeat. The capacity to respond to the immediate situation determined success: 'The secret of Napoleon was to meet events half-way so that he could control them, instead of waiting and allowing them to over-ride him' $\cdot{ }^{15}$ During the Cold War, because it never turned hot, plans were not ever trumped by circumstances, and so theory prevailed, untrammelled by contact with reality.

Strategic theory, as developed before 1914 by professional soldiers like Foch and his predecessors, sought to understand war as a general phenomenon. It did so in two ways. One, the doctrinal thread, owed its intellectual origins to Jomini, whose biography by Jean-Jacques Langendorf is revealingly and rightly called Faire la guerre, how to 'do' war. ${ }^{16}$ Jomini's method centred on planning, and laid down the principles which would deliver strategic success, using cartography and geographical awareness to manoeuvre and to master lines of communications. The other approach, which we owe to Clausewitz, is best understood in the title of Raymond Aron's book on him, Penser la guerre, or how to 'think' about war. ${ }^{17}$ Here the role of theory is to prompt strategic thought as a route to comprehension rather than to action. The departure point is the need to think before acting, recognising that it is important to get the questions right before jumping to conclusions. If the initial questions are wrong, then the answers are likely to be too.

\footnotetext{
${ }^{14}$ Commandant Bugnet, Foch Talks, translated by Russell Green (London: V. Gollancz Ltd 1929), 191.

is Raymond Recouly, Marshal Foch: His Own Words on Many Subjects, translated by Joyce Davis (London: Thornton Butterworth 1929), 100, 128.

${ }^{16}$ Jean-Jacques Langendorf, Faire la guerre: Antoine-Henri Jomini (2 vols, Geneva: Georg 20012004).

${ }^{17}$ Raymond Aron, Penser la guerre, Clausewitz (2 vols, Paris: Gallimard 1976).
} 
Strategic theory, certainly until 1914 and even until 1945, sought continuities. It was a dialogue between the present and the past, aiming to put current conflicts in context by comparing them with those of history. So both Clausewitz and Jomini turned to the wars of Frederick the Great to provide a way of measuring their own experiences in the wars of the French Revolution and Napoleon. History enabled them to understand what was enduring and what novel, and to distinguish between the two - in other words to manage the relationship between continuity and change. Once it had sorted out the new from the familiar, theory then had to decide whether the innovations were lasting or temporary, and if the former to incorporate them in the body of received strategic wisdom._Self_evidently, Strategic theory constructed on these lines could_be slow to not anticipate change and indeed might be slow to recognise it. In an area of study whose prime motivation is prudential and anticipatory, that is a significant disadvantage. Since 1945 strategic theory has used disciplines other than history, such as game theory, mathematics and economics, to give it a better purchase on the future, albeit without any more obvious signs of success. In the process its hold on historical precedent has become tenuous, and so it has not been as effective in its capacity to recognise and assimilate what is genuinely new as opposed to what only seems to be new. This is why Colin Gray and others have used history in the ways which they have - to reinstate the perceptions derived from the continuities in strategic theory.

Strategy in practice is not like that. This is so for three reasons. The first and most important is that there is no universal character to war. War may have its own nature: it rests on reciprocity, on the clash of wills with which Clausewitz begins chapter 1, book I of Vom Kriege. Violence, the business of killing and being killed, lies at its core. It requires courage of its participants and it is shaped in circumstances which are confusing and profoundly challenging. But what follows from all this is that each war is in practice very different, possessed of its own characteristics. War at sea is not the same as war on land, and within 
war at sea the battle of Salamis was very different from the battle of Jutland, and both were different again from the battle of Midway. Recent military experience makes a similar point. For those who served in both Iraq and Afghanistan, there were some similarities between the two theatres. Ultimately the United States and its allies tried to apply common principles in the shape of counter-insurgency warfare. In practice, however, the two countries provided operating environments which were fundamentally different, in culture, history, geography, religious practice, literacy and economic potential. All these could make the ready acceptance of superficial commonalities positively dangerous. Generalised operating principles make sense for hierarchical organisations like armies, but they militate against the exploration of difference, even if they do not absolutely preclude it. This is why we study military history: not because wars are the same, but to understand how they differ. History teaches cause and effect before it says anything about generalizable and transferable principles. Marc Bloch, the French medieval economic historian who served his country as a soldier in 1914 and 1940, made this point when he addressed the problem of why the French army, which had emerged victorious in the First World War, had been so ignominiously defeated in 1940: the value in history is that it 'is, in its essentials, the science of change'. The French army of 1940 had not realised this, believing instead that history repeated itself, a point which every historian knows to be untrue. ${ }^{18}$

The second challenge for strategy in practice is that we are told that wars are the continuation of politics by other means, when they are not, and particularly not for democratic states. Policy generates change over very short lead-times. The 1997-98 British Strategic Defence Review aspired to be long-term and prudential: it was even praised because

${ }_{18}^{18}$ Marc Bloch, Strange Defeat: A Statement of Evidence Written in 1940, translated by Gerard Hopkins (New York: Norton 1999), 117-118. Bloch's portrayal of French military education in the inter-war period overplays the influence of Napoleon and underplays the real effort to engage with the lessons of the First World War, but his more general argument stands. 
it was 'strategy-led'. However, its assumptions were overthrown by the responses of the United States and its allies to the 9/11 attacks. The review had set out to create a maritime-air capability for expeditionary war, which assumed that short-term overseas interventions would be the norm. In practice Britain fought two protracted campaigns in Iraq and Afghanistan in which the army led, and in which the capability decisions of 1997-98, predicated on aircraft carriers and multi-role combat aircraft, were trumped by so-called 'urgent operational requirements', running from armoured vehicles to drones. For most western democracies, going to war represents a decision for change, not continuity. It reflects a recognition that the previous policy has failed and that a new approach is required.

Furthermore, recent conflicts show that it is not just the initial decision to go to war which resets policy. The destabilising influences of democratic politics permeate war once hostilities have commenced, often undermining strategy itself. The effort to establish a coherent campaign plan for the war in Afghanistan was constantly reset by the need to adjust to changing political objectives. For some the aim was the defeat of al-Qaeda in Afghanistan; for others it was the overthrow of the Taleban; and for a third group it was the construction of a viable Afghan state capable of running its own affairs in ways that respected human rights and the rule of law. The United States itself oscillated along this spectrum, and its allies positioned themselves on it at different points at different times. The effects, while preventing strategy from developing any consistency, at least proved - albeit negatively - that war can indeed be the continuation of policy by other means. Governments, however, run the risk that policy itself will be subordinated to the contingencies of war, particularly if the war becomes protracted and then goes in unpredicted directions. They too easily forget that the enemy has a vote and is ready to meet force with force. Loss of life in war all too often becomes a reason for continuing it, in order to justify and hallow the loss: 'our boys' cannot have died in vain. The effect of killing and death can render a return to the status quo ante all but impossible. 
That is true for pragmatic reasons as well as emotional. In August 1914 the British Parliament rushed through the Defence of the Realm Act in order to deal with German spies. The orders passed under the terms of the act left a legacy after the end of the war in 1918 which continued to shape the patterns of daily life in Britain for decades, from the opening hours of pubs to the introduction of British summer time. In 2009, the United States formally abandoned the global war on terror when its progenitor, George W. Bush, was succeeded as president by Barack Obama, but many of the structures put in place then - ranging from airport security to the detention facility in Guantanamo bay - remain.

Thirdly, once war becomes policy, politicians in democratic states become the de facto strategists. Few of them, however, have studied strategic theory. This was General Ripper's point: strategy is studied in staff colleges and military academies by those whose careers will be in uniform. Between 1864 and 1870 the Prussian minister president, Otto von Bismarck, used war to further the interests of his policies better than most in the history of modern Europe. He unified Germany by 1871 through a sequence of wars, which were short enough to be concluded before other powers were drawn in and sufficiently decisive to ensure that they did not in fact trump his policy, but served it. Bismarck was the exception who was used to prove the rule, but he did not consider himself a strategist. Today we associate the trite generalisation that war is the continuation of policy by other means with Carl von Clausewitz, another Prussian and one whose study of war, Vom Kriege, first published just over three decades before, had come out in a revised edition as recently as 1853. However, there is no evidence that Bismarck ever read Clausewitz. Bismarck owed his success to common sense, not to strategic theory.

As a statesman not formally versed in strategic theory, he was then - and remains today - hardly unusual. As George W. Bush girded the United States for war in 2002, Eliot Cohen published an influential study of democratic political leaders as strategic practitioners. 
Called Supreme command, it looked at four case studies - Abraham Lincoln in the American Civil War, Georges Clemenceau in the First World War, Winston Churchill in the Second World War, and David Ben-Gurion in Israel's War of Independence. Each of them read widely, but only Churchill had read deeply in strategic theory: as a young man, for all that he was a cavalry subaltern who liked to trumpet his lack of formal education, he asked his doting mother to send him the latest professional publications. This was an era, sandwiched between the Franco-Prussian War and the First World War, when military publishing flourished, and did so internationally. But Churchill did not overtly refer to those texts as a wartime leader in either world war. Instead his early morning reading as prime minister was dominated by the latest intelligence intercepts. For him, as for Cohen's other three subjects, strategy was a profoundly pragmatic business, shaped by the realities of the moment, as they endeavoured both to meet contingency head on while retaining an overall sense of direction.

We might question how far they provide a model of supreme command for the wars of the early twenty-first century. Because they were engaged in wars of national survival, their premierships were defined by their mastery of strategy. In this they differed from George W. Bush and even more from his peers among the United States's allies. For them the 'global war on terror', despite the grandiloquence of its title, never subordinated the other affairs of state to the needs of war. Policies pursued in relation to housing or health or education continued to have their own priorities and values, and demanded their attention at least as much as did foreign affairs and military operations. The war was not used to raise taxes or to explain the fiscal deficit or to justify the financial crash of 2008 . By contrast, for Cohen's gang of four, the policy was war, and their wars dominated their policies in other areas, including the management of the economy. The practitioners of strategy in the early $21^{\text {st }}$ century have never allowed themselves - or been allowed - to develop that single-minded focus, even if they have had the appetite for it. 
Those versed in maritime strategy might with good reason argue that this account exaggerates the polarity between strategy in practice and strategic theory, and does so because it over-estimates the role of continental Europe, with its land wars waged by armies, and underplays the role of empire, trade and maritime expansion. Wars at sea have struggled to find their place in mainstream strategic theory. The early running in the post-Enlightenment tradition of writing on war was made by men like Jomini and Clausewitz, soldiers with a theoretical caste of mind, and focused on land warfare. Writers like Alfred Thayer Mahan and Julian Corbett did not enter the fray until the turn of the nineteenth and twentieth centuries, almost a hundred years later. Both of them wrote books which were directly informed by their landed predecessors, Mahan's by Jomini and Corbett's by Clausewitz, and yet both had a more ambivalent relationship with the centrality of battle in warfare. As Corbett put it, when addressing the 'maxim' that the only way of securing command of the sea 'is to obtain a decision by battle against the enemy's fleet', 'nothing is so dangerous in the study of war as to permit maxims to become a substitute for judgment' ${ }^{19}$ He went on to stressed the role of blockade rather than battle in securing command of the sea. Furthermore, both he and Mahan were well aware that the foundations of maritime power were built in peace rather than in war. Maritime power in 'a globalised world', a phrase that seemed as appropriate to them as it does today, with its patterns of international trade sustained by the City of London and the convertibility of the pound sterling, depended on the acquisition of bases and the long-term construction of fleets. For imperial and trading powers like the United States and Britain, maritime strategy related much more directly to the pursuit of policy outside war than did the understanding of strategy promoted by Jomini or

19 Julian Corbett, Some Principles of Maritime Strategy (1911), edited by Eric Grove (Annapolis, MD: Naval Institute Press 1988), 167. Lukas Milevski, The Evolution of Modern Grand Strategic Thought (Oxford: Oxford University Press 2016) sees the origins of its subject in maritime strategy. 
Clausewitz. It was also a persistent feature of national policy, not -as major war was - an episodic and infrequent response to abnormal circumstances.

Imperial and maritime power was also predicated on a 'rules-based international order' - or the capacity to challenge those rules. If maritime strategy possessed earlier origins than those associated with Mahan and Corbett, or even than Jomini and Clausewitz, they are to be found in the development of international law. The career of Hugo Grotius, the author $D e$ jure belli et pacis, published in 1625, highlights two important points about the effect of law on strategic theory. First, the sea provided the test bed for his ideas on the relationship between law and war before Europe was assailed by the impact of the Thirty Years War (1618-48). Grotius was employed by the Dutch East India Company to represent it in a case concerning prize law at sea. He produced a commentary on the law of prize and booty, and the part which addressed the freedom of the seas (and asserted it as a principle) was published in 1609. As the power of the centralised state extended in terms of territorial control and effective administration, particularly in Europe after 1648, the sea - by contrast - remained an unregulated space, where piracy and brigandage co-existed with more regular forms of war. The practice of state privateering - giving vessels letters of marque to attack enemy cargos was not finally outlawed until the treaty of Paris at the end of the Crimean War in 1856. It was a fragile equilibrium: in the First World War international maritime law was challenged in theory and in practice by both sides. After it, Britain remained as resistant to the principle of the freedom of the seas (proposed by the United States as part of the peace settlement), as it had been to Grotius three hundred years earlier. ${ }^{20}$

${ }^{20}$ John W. Coogan, The End of Neutrality: The United States, Britain and Maritime Rights, 18991915 (Ithaca, NY: Cornell University Press 1981); Isabel Hull, A Scrap of Paper: Making and Breaking International Law during the Great War (Ithaca, NY: Cornell University Press 2014); Bernard Semmel, Liberalism and Naval Strategy: Ideology, Interest, and Sea Power during the Pax Britannica (Boston: Allen \& Unwin 1986). 
Corbett, himself trained as a lawyer, was clear that economic warfare was a cardinal weapon in Britain's armoury, a point which he had developed in Some principles of maritime strategy before the First World War, and which he and others believed had been vindicated by its outcome. International law - and specifically the Declaration of London of 1909 - tried to pin down a tight definition of contraband, in order to ensure that belligerent states could only seize goods which were directly defined as munitions of war. This was not how Corbett saw the purposes of blockade. 'If on land you allow contributions and requisitions, if you permit the occupation of towns, ports, and inland communications, without which no conquest is complete and no effective war possible, why should you refuse similar procedure at sea where it causes far less individual suffering?', he argued in 1911. What really brings war to an end, he went on, is the exertion of 'pressure on the citizens and their collective life'. ${ }^{21}$

Corbett's version of economic war, and Britain's practice of it in the First World War, legitimised attacks on civilians. It was the revolution in Germany, not its army's defeat on the western front, which had ended the war in November 1918, in the eyes not just of German generals anxious to argue that they had been 'stabbed in the back' but also of maritime strategists. This was the second contribution of maritime strategy to strategic theory: that, especially in 'total wars' fought by democracies, the people of the nation had a responsible role in the making of strategy and in the making of war. Economic warfare could target the people, especially by denying them food, and so force them into revolution against the state which had taken them into war. The apparent success of this approach fed the arguments for strategic bombing almost from the outset. As Giulio Douhet looked at the First World War from the perspective of Italian neutrality in 1914, he anticipated it would end in revolution,

\footnotetext{
${ }^{21}$ Corbett, Some Principles of Maritime Strategy, 97.
} 
and by 1921 this belief underpinned his arguments for the efficacy of air power. ${ }^{22}$ In 1944 the western allies believed that Germany would collapse before the end of that year because its people, under sustained attack from the air, would overthrow Hitler, just as in 2003 the Americans convinced themselves that Iraqis would welcome them because they would have overthrown Saddam Hussein. ${ }^{23}$

Here were approaches to strategy, generated in peacetime, linked to the growth of democracy, and bridging the gap between the use of war and its utility for national policy, which took strategy in new directions. In the United Kingdom, the phrase 'grand strategy' gained currency in the 1920s and 1930s, and it was employed successfully as an organising tool in the Second World War. It turned the concepts of full national mobilisation, coalition warfare and multi-front campaigning, waged in the three dimensions of land, sea and air, into a workable framework. After the war was over, the United States encapsulated a similar set of ideas in 'national strategy', a title which reflected the National Security Act of 1947. Congress said that the role of the National Security Council, set up under the act, was to 'advise the President with respect to the integration of domestic, foreign, and military policies' ${ }^{24}$

The Cold War and its accompanying vocabulary of deterrence allowed the nostrums of grand and national strategies to continue to hold good. The 'hot wars' waged within its framework were not seen as wars of national survival for the major powers, but were defined as limited wars, small wars, counter-insurgency campaigns and low-intensity operations.

${ }_{22}$ Thomas Hippler, Bombing the People: Giulio Douhet and the Foundations of Airpower Strategy, 1884-1939 (Cambridge: Cambridge University Press 2013).

${ }^{23}$ F. H. Hinsley and others, British Intelligence in the Second World War: Its Influence on Strategy and Operations (4 vols, London:_Her Majesty’s Stationery Office 1979-1990), 3/2, 365; Richard Overy, The Bombing War: Europe 1939-1945 (London: Allen Lane 2014).

${ }^{24}$ William Burr, 'National Security Council', in John Whiteclay Chambers II (ed.), The Oxford Companion to American Military History (Oxford: Oxford University Press 1999), 470. 
They might be lumped together as part of the wider ideological struggle against communism but, as long as that bigger contest was contained, that argument was itself a theoretical as well as an ideological construct. War and strategy were set on divergent courses without anybody really noticing until after the end of the Cold War. Since then broad notions of grand strategy have struggled to sustain their momentum. The reduction of the role of deterrence in public rhetoric; the belief - however naïve - that major war has had its day; the elevation of terrorism in the public discourse on national security: all militate against broad definitions of strategy. At the same time, especially since $9 / 11$, there have been wars in abundance but none which ostensibly merits inclusion within a big concept like grand strategy. To revalidate itself, grand strategy - at least in the US - has assumed more open-ended and long-term objectives, concerned as much with domestic arguments about national strength and resilience, including health, education and the institutions of democracy. The specifics of individual wars have not readily accommodated themselves to this narrative, which in any case tends to downplay contingency and even the impact of external adversaries. ${ }^{25}$

Outside the United States, its allies are less sure that they have any need for grand strategy at all, not least because of their subordinate status, and the Americans reinforce this conviction by insisting that only a great power has need of a grand strategy. For Britain specifically, grand strategy has been dismissed as a legacy of empire. ${ }^{26}$ The most obvious

${ }_{25}^{5}$ Hal Brands, What Good is American Grand Strategy? Power and Purpose in American Statecraft from Harry S. Truman to George W. Bush (Ithaca, NY: Cornell University Press 2014). Ionut Popescu, Emergent Strategy and Grand Strategy: How American Presidents Succeed in Foreign Policy (Baltimore: Johns Hopkins University Press 2017) makes the case for responding to contingency in grand strategy.

${ }^{26}$ House of Commons Public Administration Committee, Who does UK National Strategy? First report of session 2010-11, HC435 (18 October 2010), 8-9; Williamson Murray, 'Thoughts on Grand Strategy', in Williamson Murray, Richard H. Sinnreich and James Lacey (eds.), The Shaping of Grand Strategy: Policy, Diplomacy, and War (Cambridge: Cambridge University Press 2011), 1. 
symptom of this malaise relates to the poverty of the public debate around one of the principal props - and even origins - of grand strategy. Although the debate on strategy was re-energised by the effects of the global war on terror, and of the wars in Iraq and Afghanistan, that on maritime strategy specifically has stuttered. ${ }^{27}$ The naval professionals of traditional sea powers, including the United States and the United Kingdom, complain about the sea blindness of their peoples. The latter, they say, fail to appreciate their dependence on the security of the sea, and don't notice the centrality of the sea to world trade, the interdependence of national economies in an era of globalisation, and the proximity of most of the world's population to the sea. None of this is untrue or unimportant, but it is also a statement of the obvious, which does not in itself explain why powers need highly sophisticated aircraft carriers, destroyers, frigates or nuclear submarines, all optimised for conflicts between peer rivals. It does not draw the specific connection of navies to war, to what classical maritime strategy called sea control or sea denial. Instead it makes a virtue of the diplomatic and political leverage provided by a maritime presence. In so doing it links the theory of sea power to the practice of policy and commerce, and not to strategy itself.

The response of soldiers to the evidence of a divergence between strategy in theory and strategy in practice since $9 / 11$ has been very different. They have reverted to the position adopted by their nineteenth-century predecessors. Traditional strategic theory responded to the unpredictable effects of policy on the conduct of war by effectively discounting it. By seeing strategy as a self-contained area of military professional competence, they stressed its

${ }^{27}$ Exceptions to this generalisation include Geoffrey Till, Seapower: A Guide for the TwentyFirst Century (Abingdon: Routledge 2013), Chris Parry, Super Highway: Sea Power in the $21^{\text {st }}$ Century (London: Elliott and Thompson 2014), and Daniel Moran and James Russell (eds.), Maritime Strategy and Global Order: Markets, Resources, Security (Washington DC: Georgetown University Press 2016). 
relationship to tactics, not to politics, to the use of the battle for the purposes of the war, not to the use of war for the purposes of policy.

This way out was foreshadowed before the end of the Cold War by the emergence of operational art in military thought in the 1980s. Two pressures contributed to this. One was the defeat of the United States in Vietnam. Operational doctrine became a tool to rebuild the army's sense of self-regard, best embodied in Field Manual 100-5: Operations, in its 1982 edition. The other was the need for NATO armies on the inner German border, pre-eminently those of Britain and West Germany itself, to address how they would deal with a conventional attack launched by the Warsaw Pact. NATO, under pressure not to escalate to nuclear weapons too soon, if at all, had to come up with more effective conventional solutions to the conduct of land warfare. They were not strategy: that was set by the stand-off in Europe between NATO and the Warsaw Pact. But they looked like strategy as defined by military thinkers from Clausewitz to Foch, and they presented policy-makers with operational alternatives which could shape their strategies in practice. They also re-empowered soldiers in the making of strategy, by opening the door to military expertise and revalidating old principles like manoeuvre and surprise. The approach was never tested in Europe, but the allies' success in the first Gulf War of 1990-91, when they were able to defeat a numerically stronger Iraqi army fighting a defensive battle, provided an operational solution to a seemingly intractable political problem. The 1992 memoirs of the allied and US commander in the Gulf War, Norman H. Schwarzkopf, are indicative. The index's heading for strategy said see 'military art', and the sub-headings under military art ran from 'breaching operations' to 'unity of command' by way of such subjects as 'desert warfare, training for' and 'logistics'. Schwarzkopf did not address strategy as Steven Jermy or John Stone was to do so in 2011: he eschewed politics and his own index entry described himself as a 'military strategist and tactician'. As an infantry captain at Fort Benning, Schwarzkopf had won the 
George C. Marshall Award for Excellence in Military Writing with an essay which described a day of fighting. Only at the end was the protagonist revealed as Julius Caesar. Schwarzkopf said he had written it 'to demonstrate the timelessness of the principles of war' ${ }^{28}$

When confronted with shifting policies in relation to the wars in Iraq and Afghanistan, generals who had been subalterns in the 1980 s reverted to what for them provided continuity and operational direction. In 2008 General James Mattis, the US Joint Force Commander and a marine, wrote of the need 'to return to time-honored principles and terminology that our forces have tested in the crucible of battle and that are well grounded in the theory and nature of war' ${ }^{29}$ Others in the British and French armies made similar points at the same time. These generals were using strategy in theory to put shape on the wars that they faced, and did so by generalising - as Jomini and Clausewitz had done - from the experience of one war by putting it in the context of war as a general phenomenon. It was an important corrective. It put war back into strategy; it served to remind politicians that the enemy would frustrate their plans; that wars have their own dynamics; and that wars is not an instrument to fulfil the ends of policy in a pure and directed way. In short war is a reactive process, which itself can change policy.

As in earlier efforts to do that, military thought was more comfortable with the relationship between strategy and tactics than that between strategy and policy. Three interconnecting problems therefore persisted. First, this approach did not of itself reconnect strategy in theory with strategy in practice. Secondly, in their focus on war soldiers were saying things which did not - despite the era of joint warfare - relate to what sailors were saying about strategy, which was more about trade and diplomacy than about fighting. The

${ }_{28}$ H. Norman Schwarzkopf, The Autobiography: It Doesn't Take a Hero, written with Peter Petrie (London: Bantam Books 1992), 97, 145, 521-522, 526, 527.

${ }_{29}$ James Mattis, 'USJFCOM Commander's Guidance for Effects-Based Operations', Parameters

(Fall Autumn 2008), 18-25, 18. 
two were speaking past each other. Thirdly, the soldiers' operational focus was not tied in to defence policies, with the obvious danger that states generated national security strategies which failed to learn lessons from the immediate past. The most obvious example is the enquiry into the war in Iraq chaired by Sir John Chilcot for the British government, which reported in 2016, too late to influence the 2010 or 2015 National Security Strategies, and with little public expectation that it would shape their successors.

As a result the United States and its allies have persisted in strategic failure. Because operational thought has been more coherent than strategy, the former has entered the space vacated by the latter, posing as something it is not, and failing to deliver as a result. ${ }^{30}$ There are sins of omission and commission on both sides of the military-civil divide. Soldiers have presented counter-insurgency doctrine as a strategy when in fact it is an operational method. Politicians have become embroiled in tactical fixes to strategical problems, most openly through the use of drones (or unmanned aerial or remotely piloted vehicles) for the targeted killing of enemy leaders, and more discreetly through the deployment of special forces. These tactical and operational methods are exactly that: means which need to be allied to ends if they are to have strategic purchase.

Solutions to these challenges are not straightforward, but they need to begin with an awareness of the distinctions between operations and strategy, and between 'military' strategy and 'grand' strategy, however confused those differences become in practice and even in planning. Above all, debate should be informed by the recognition of the distinction between strategy in theory and strategy in practice. That does not mean that these two approaches are choices: they are neither alternatives nor optional. Both are required, and they need to be related one to the other. Strategy in theory, knowledge of war's nature, has to

\footnotetext{
${ }^{30}$ Two of the most forceful critics were Douglas Porch, Counterinsurgency: Exposing the Myths of the New Way of War (Cambridge: Cambridge University Press 2013), and Gian Gentile, Wrong Turn: America's Deadly Embrace of Counter-Insurgency (New York: The New Press 2013).
} 
inform strategy in practice. The former seeks continuity and ongoing principles; the latter embraces constant change and unpredictability. Each has a role in helping the other.

The intellectual framework for this relationship requires institutional expression.

Coherent governmental machinery can give effect to these aspirations, shaping the dialogue between the two. Theory enables an informed discussion between the chiefs of staff and their political masters, in order to find a viable balance between military means and political ends. As Corbett wrote in 1911,

Nor is it only for the sake of mental solidarity between a chief and his subordinates that theory is indispensable. It is of still higher value for producing a similar solidarity between him and his superiors at the Council table at home. How often have officers dumbly acquiesced in ill-advised operations simply for lack of the mental power and verbal apparatus to convince an impatient Minister where the errors of his plan lay? ${ }^{31}$

He went on, 'Conference is always necessary, and for conference to succeed there must be a common vehicle of expression and a common plane of thought. It is for this essential preparation that theoretical study alone can provide, and herein lies its practical value. ${ }^{32}$

Another way of viewing the problem is to ask three questions. First, who thinks about strategy? Second, who decides strategy? Third, who does strategy? Although today academics and think tactics undoubtedly address the first question, it is professional military education which gives strategic thought the most sustained attention. It is nonsensical not to give those who have been the beneficiaries of that schooling a voice in council. However, the answer to the second question - at least in a modern democracy - is the government, which takes the political responsibility for the strategy which is eventually adopted. Its policy may be the right one, but that is not the end of the story. The decision requires implementation,

\footnotetext{
${ }^{31}$ Corbett, Some Principles of Maritime Strategy, 5.

${ }^{32}$ Corbett, Some Principles of Maritime Strategy, 8.
} 
and here the armed forces re-enter the equation, at least in the event of war. Failures in execution or successful responses by the enemy change the situation on the ground. At that point the armed forces have to be involved take in any decision about the need to moderate the ends which are being sought or about finding a different route to their fulfilment.

In these deliberations, strategy needs to be modest about itself and about what it can deliver. It is, after all, more of an art than a science, and it behoves those who think about it and those who practice it not to be too brazen about its status. ${ }^{33}$ Its principles may be guidelines, but, as strategic theorists who are worth their salt have stressed, they are not rules. Precisely because strategy is a pragmatic business it lacks the clarity and purity which strategic theory so often seeks. Strategy has to be reactive as well as predictive, and it must be open to new evidence, whether presented as intelligence or acquired as experience. Strategic theory 'can at least determine the normal', Corbett wrote, and 'having determined the normal, we are at once in a stronger position', not least because 'we can proceed to discuss clearly the weight of the factors which prompt us to depart from the normal'. ${ }^{34}$

\footnotetext{
${ }_{33}$ Everett Carl Dolman, Pure Strategy: Power and Principle in the Space and Information Age (London: Frank Cass 2003), 188-194, makes the case for strategy as an art.
} ${ }^{34}$ Corbett, Some Principles of Maritime Strategy, 9. 


\section{Bibliography}

Aron, Raymond, Penser la guerre, Clausewitz (2 vols, Paris: Gallimard 1976).

von Bernhardi, Friedrich, Vom Kriege der Zukunft. Nach der Erfahrungen des Weltkrieges

(Berlin: E.S. Mittler \& Sohn 1920).

Bloch, Marc, Strange Defeat: A Statement of Evidence Written in 1940, translated by Gerard Hopkins (New York: Norton 1999).

Brands, Hal, What Good is American Grand Strategy? Power and Purpose in American Statecraft from Harry S. Truman to George W. Bush (Ithaca, NY: Cornell University Press 2014).

Bugnet, Commandant, Foch Talks, translated by Russell Green (London: V. Gollancz Ltd 1929).

Burr, William, 'National Security Council', in John Whiteclay Chambers II (ed.), The Oxford Companion to American Military History (Oxford: Oxford University Press 1999).

von Clausewitz, Carl, On War, translated and edited by Michael Howard and Peter Paret (Princeton University Press: Princeton 1976).

Coogan, John W., The End of Neutrality: The United States, Britain and Maritime Rights, 1899-1915 (Ithaca, NY: Cornell University Press 1981).

Corbett, Julian, Some Principles of Maritime Strategy (1911), edited by Eric Grove (Annapolis, MD: Naval Institute Press 1988).

Coutau-Bégarie, Hervé, Traité de stratégie ( $6^{\text {th }}$ edition, Paris: Economica 2008).

Dolman, Everett Carl, Pure Strategy: Power and Principle in the Space and Information Age (London: Frank Cass 2003).

Gaddis, John Lewis, On Grand Strategy (London: Allen Lane 2018).

Gentile, Gian, Wrong Turn: America's Deadly Embrace of Counter-Insurgency (New York: The New Press 2013).

Gray, Colin S., Modern strategy (Oxford: Oxford University Press 1999).

Gray, Colin S., The Strategy Bridge: Theory for Practice (Oxford: Oxford University Press 2010).

Hinsley, F. H. and others, British Intelligence in the Second World War: Its Influence on Strategy and Operations (4 vols, London: Her Majesty's Stationery Offices 19791990).

Hippler, Thomas, Bombing the People: Giulio Douhet and the Foundations of Airpower Strategy, 1884-1939 (Cambridge: Cambridge University Press 2013). 
House of Commons Public Administration Committee, Who does UK National Strategy?

First report of session 2010-11, HC435 (18 October 2010).

Howard, Michael, The Causes of Wars and Other Essays (London: Temple Smith 1983).

Hull, Isabel, A Scrap of Paper: Making and Breaking International Law during the

Great War (Ithaca, NY: Cornell University Press 2014).

Jermy, Steven, Strategy for Action: Using Force Wisely in the $21^{\text {st }}$ Century (London:

Knightstone Publishing 2011).

Joint Doctrine Publication 01: Joint Operations (Joint Doctrine and Concepts Centre March 2004).

Langendorf, Jean-Jacques, Faire la guerre: Antoine-Henri Jomini (2 vols, Geneva: Georg 2001-2004).

Liddell Hart, Basil, The decisive wars of history: a study in strategy (London: G. Bell \& Sons Ltd 1929).

Liddell Hart, Basil, When Britain Goes to War: Adaptability and Mobility (London: Faber \& Faber 1932).

Liddell Hart, Basil, The Strategy of the Indirect Approach (London: Faber \& Faber 1942).

Luttwak, Edward N., The Grand Strategy of the Roman Empire: From the First Century A.D. to the Third (first published 1976; London: Weidenfeld \& Nicolson 1999).

Luttwak, Edward N., The Grand Strategy of the Byzantine Empire (Cambridge MA: The Belknap Press of Harvard University Press 2009).

Mattis, James, 'USJFCOM Commander's Guidance for Effects-Based Operations', Parameters (Autumn 2008), 18-25.

Milevski, Lukas, The Evolution of Modern Grand Strategic Thought (Oxford: Oxford University Press 2016).

Moran, Daniel and James Russell (eds.), Maritime Strategy and Global Order: Markets, Resources, Security (Washington DC: Georgetown University Press 2016).

Murray, Williamson, 'Thoughts on Grand Strategy', in Williamson Murray, Richard H.

Sinnreich and James Lacey (eds.), The Shaping of Grand Strategy: Policy, Diplomacy, and War (Cambridge: Cambridge University Press 2011).

Napoléon, De la guerre, presenté et annoté par Bruno Colson (Paris: Perrin 2011).

Overy, Richard, The Bombing War: Europe 1939-1945 (London: Allen Lane 2014)

Parker, Geoffrey, The Grand Strategy of Philip II (New Haven, CT: Yale University Press 1998). 
Parry, Chris, Super Highway: Sea Power in the 21 ${ }^{\text {st }}$ Century (London: Elliott and Thompson 2014).

Popescu, Ionut, Emergent Strategy and Grand Strategy: How American Presidents Succeed in Foreign Policy (Baltimore MD, Johns Hopkins University Press 2017).

Porch, Douglas, Counterinsurgency: Exposing the Myths of the New Way of War (Cambridge: Cambridge University Press 2013).

Recouly, Raymond, Marshal Foch: His Own Words on Many Subjects, translated by Joyce Davis (London: Thornton Butterworth 1929).

Schwarzkopf, H. Norman, The Autobiography: It Doesn't Take a Hero, written with Peter Petrie (London: Bantam Books 1992).

Semmel, Bernard, Liberalism and Naval Strategy: Ideology, Interest, and Sea Power during the Pax Britannica (Boston: Allen \& Unwin 1986).

Stone, John, Military Strategy: The Politics and Technique of War (London: Continuum 2011).

Till, Geoffrey, Seapower: A Guide for the Twenty-First Century (Abingdon: Routledge 2013). 